\title{
Dealing with a disagreeing partner: Relational and epistemic conflict elaboration
}

Céline Darnon

Sébastien Doll

Université Pierre Mendès France, Grenoble, France

Fabrizio Butera

Université de Lausanne, Suisse

This experiment examined the effects of epistemic vs. relational conflicts on the relationship with a partner. Students participated to a fictitious computer-mediated interaction about a text with a bogus partner who introduced either an epistemic conflict (a conflict that referted to the content of the text), or a relational conflict (a conflict that questioned participants' competence). Results indicated that compared to the epistemic conflict, the relational conflict enhanced threat and reduced the perceived contribution of the partner. Moreover, after a relational conflict, participants were more assertive in their answers, justified them to a lower extent, and expressed less doubt than affer an epistemic conflict. Results also indicated that the intensity of disagreenent predicted different modes of regulation depending on the conflict type. Finaly, epistemic conflict elicited better learning than relational conflict.

Use soft words and hard arguments.

(English proverb)

Many situations where knowledge is at stake may engender discussions and debates. Classes, scientific conferences, research Jabs, or any discussion between people about a given topic are examples of these kinds of situations. Let us examine for example the following conversation between Megan and Kelly who are working together on their homework:

Céline Darnon is now at the Laboratoire de Psychologie Sociale et Cognitive, Université Blaise Pascal, ClermontFerrand. This work was supported by an "Ecole et Sciences Cognitives" fund granted by the French Mlinistry for Research, and by he Swiss National Science Foundation. 
$\mathrm{M}$ : What was your answer for question 2 ?

$\mathrm{K}$ : I answered " $\mathrm{X}$ "

M: Hum. I thought the answer was "Y".

$\mathrm{K}$ : I don't think so because...

M: I see. Then how come...?

K: Probably because...

Most of us have probably been involved in this kind of discussion. Most of us could then probably attest to how stimulating these discussions can be. This is also attested by many researchers who refer to this situation as to "socio-cognitive conflict" (Doise \& Mugny, 1984; Mugny, De Paolis, \& Carugati, 1984) or "controversy" (Johnson \& Johnson, 1994). For these authors, socio-cognitive conflict can be the key of cognitive growth (Doise \& Mugny, 1984), elaborated reasoning strategies (Butera \& Mugny, 1995), epistemic curiosity (Berlyne, 1960), quality of reasoning (Johnson, Johnson, \& Smith, 2000; Smith, Johnson, \& Johnson, 1981) or learning (Lowry \& Johnson, 1981; for reviews, see Buchs, Butera, Mugny, \& Darnon, 2004; Butera \& Buchs, 2005; Doise \& Mugny, 1984; Tjosvold, 1989). In the above example, it is likely that after discussing the solution with Kelly, Megan would be able to reach a more elaborated level of understanding of the problem than if Kelly had agreed with her.

However, most of us could probably also attest that sometimes, debate turns in such a way that instead of rendering individuals creative and cognitively stimulated, it makes them feel particularly bad, threatened, and cognitively inhibited. Let us have a look now at the following example:

M: What was your answer for question 2 ?

$\mathrm{K}$ : " $\mathrm{X}$ " of course, the answer is obvious.

M: Hum. 1 thought the answer was "Y".

$\mathrm{K}$ : How can you think the answer is "Y"? You should know that...

$\mathrm{M}$ : I see. Then how come...?

$\mathrm{K}$ : If you had listened to what the teacher said, you would know that...

Will Megan's reaction be the same as before? Will she perceive Kelly in the same way as she did before? Will this confrontation lead to the same cognitive process as in the previous example? In other words, what happens when, as in the above example, the conflict switches from the question of knowledge to the question of competence? The focus of the present paper will be to address this question, by comparing people's reaction to two different types of conflicts.

\section{Two types of conflict}

Much research has shown that the effect of socio-cognitive conflict highly depends on the situation in which it takes place (for reviews, see Buchs, Butera, Mugny, \& Damon, 2004; Butera \& Mugny, 2001; Mugny, Butera, Quiamzade, Dragulescu, \& Tomei, 2003). Butera and Mugny (1995), for example, showed that conflict could lead low-competence participants to an improvement in their reasoning strategies, unless a competence-threatening conpetition was introduced (see also. Johnson \& Johnson. 1985). In the same line, it was shown that conflict between high-competence participants led to trying to defend and protect one's own self-competence and tejecting the other's point of view - with disruptive effects on reasoning - unless competition was hindered (Butera, Gardair, Maggi, \& Mugny, 1998; Butera, Mugny, \& Tomei, 2000). Other research demonstrated that students could learn from a disagreement with an expert (Mugny. Tafani, Butera, \& Pigière, 1999; Quianzade. Tomei, \& Butera, 2000). However, if the latter makes then feel incompetent, this results in a superficial compliance without deep leaming. Another line of research has demonstrated that in a context enhancing 
mastery goals (importance to improve one's knowledge, to learn), confiict was beneficial for learning whereas in a context enhancing performance goals (importance to demonstrate one's ability), it was not (Darnon, Butera, \& Harackiewicz, 2007. Finally, some work has shown that conflict is beneficial, but looses its benefits when associated with putting individuals' competence into doubt (Tjosvold, Johnson, \& Fabrey, 1980; Tjosvold, Johnson, \& Lemer, 1981).

What in these situations changes the effects of a conflict? According to some authors, these situations are characterized by the fact that they do or do not threaten self-competence (Butera \& Mugny, 2001; Mugny et al., 2003; Quiamzade \& Mugny, 2001). For these authors, two types of conflicts can be distinguished: In a context in which self-competence is not threatened, the conflict can be epistemic, namely, it can be focused on the question of knowledge. This kind of conflict leads individuals into rethinking the issue, examining the validity of different propositions, and trying to understand the problem. This can result in high level cognitive processes and improvement in learning. However, if self-competence is under threat, individuals focus their attention on the question of self-competence protection instead of leaming, and the benefits of the conflict are lost. Authors qualified this type of conflict as a relational conflict.

It is worth noting that in this research, threat is considered as a factor that can result from the competitiveness of the situation (e.g., Butera \& Mugny, 1995; Johnson \& Johnson, 1985), the high competence of the source (e.g., Mugny et al., 1999), or the impossibility to consider the two points of view as complementary (e.g., Butera et al., 2000). As it was the case in the introductory example, however, we think that threat can also results from the specific rhetoric in which conflict is formulated. A great deal of work has examined the effects of different rhetorical styles in social influence, mainly opposing flexible and rigid styles. However, this research has been conducted in the domain of minority (Mugny, 1982) or high competence source influence (Mugny, Chatard, \& Quiamzade, 2006; Tomasetto, 2004). In the best of our knowledge, no research has examined this issue within same status dyads.

Moreover, the effects of epistemic $v$. relational conflict have mostly examined cognitive processing of information (as, for example, learning, cognitive growth, problem solving strategies). However, we think that these two types of conflict might not only affect the way one deals with conflictual information, but also the way one deals with the other person, that is, the relationship and the future interactions with him or her. The present study aims at addressing these two points.

\section{The rhetoric of conflict}

Even if they referred to a conflict of interest more than to a conflict of knowledge, Krauss and Morsella (2000) placed the "form of the message" as one of the most essential factors susceptible to moderate the effects of a conflict. For these authors indeed, the form of a conflict might affect the way it is perceived and solved.

In the domain of work psychology, some researchers distinguish different types of "influence tactics" (Brennan, Miller, \& Seltzer, 1993; Van Knippenberg \& Steensma, 2003; Yukl \& Tracey, 1992). Van Knippenberg and Steensma (2003) for example differentiate "hard tactics" from "soft tactics". The former are coercive and controlling (e.g., pressure, assertiveness, blocking). The latter correspond to forms that leave the target free to comply (e.g., advices, ingratiation, rationality). They showed that hard strategies are less used when people expect a future interaction with the target of influence (Van Knippenberg \& Steensma, 2003). Other research showed a negative correlation between the use of these kinds of tactics ("assertiveness" in Brennan et al., 1993; "pressure" in Yukl \& Tracey, 1992) and the effectiveness of influence (see also Maggi, Mugny, \& Papastamou, 1998, for a discussion of similar dynamics in minority influence).

More related to a conflict situation, some authors have examined the effect of different ways of expressing criticism on the future reaction to a conflict with the source of this criticism (Baron, 1988). After a criticism expressed in a threatening way ("destructive 
criticism", opposed to "constructive criticism") people reported negative feelings and were more likely to react to a conflict by either avoidance or competition. They were also less likely to collaborate than after constructive criticism.

Back to an educational context, it is interesting to note that in some research, a certain kind of conflicts seems not to be linked with positive outcomes. This is for example the case of research by Damon and Kilen (1982), who observed a negative link between the amount of conflict during an interaction and cognitive progress. In this research, however, the behaviors that were coded as "conflicts" were "rejecting acts". It is then likely that these conflicts were fairly relational in their nature. This could explain why in this research the amount of conflict was negatively correlated with progress. Actually, recent research by Quiamzade and collaborators (Quiamzade, Mugny, Dragulescu, \& Buchs, 2004; Quiamzade, Mugny, Falomir, Invernizzi, Buchs, \& Dragulescu, 2004) has specified the conditions under which a threatening thetoric induces learning or not. This research team showed that framing the transmission of conflictual knowledge in a negotiation rhetoric (democratic) achieved higher influence among expert (4th year) students than anong novice (Ist year) students, while when knowledge was transmitted in an absolute rhetoric (authoritarian) lower influence was observed among expert students than among novice students. These results are interpreted in terms of a correspondence effect between the rhetoric used and the student's representation of knowledge.

Moreover, an experiment by Monteil and Chambres (1990) suggested that a conflict may have different forms. More specifically, these authors argued that a distinction can be made between "contradiction" and "vexation". The former corresponds to a confrontation of ideas whereas the latter is more affective and aims at hurting the person. Their results indicated that the "vexation" condition led to poorer learning than the "contradiction" condition.

Finally, Darnon, Buchs, and Butera (2002) manipulated different forms of conflicts. Participants were led to interact with a confederate about a text to be learned. During the interaction, the confederate introduced a conflict, which was either "epistemic" or "relational". The epistemic conflict was focused on the text and was presented in a non-threatening way (e.g., "I'd rather say that..."; "That's weird... I thought it was the opposite..."). The relational conflict was introduced in a way that threatened participants' self-competence (e.g., "You didn't understand? Do I have to explain again?"; "For me it is quite clear, but I don't know if YOU have understood..."). In this experiment, the mode of information distribution inside the dyad was also manipulated (as in Johnson, Johnson, \& Stanne, 1989; Buchs, Butera, \& Mugny, 2004; Lambiotte et al., 1987). Indeed, participants had either complementary information or identical information, the latter having been shown to enhance competitive issues and reduce the perceived relevance of interacting with the other person (Buchs et al., 2004). Results of this study indicated that when they shared complementary information, participants leamed more after an epistemic conflict than after a relational conflict.

\section{Overview and hypotheses}

As in Damon et al. (2002), in the present experiment two different types of conflict were introduced through the rhetorical style of the partner: The conflict was either focused on knowledge (epistemic conflict) or on competence issues (relational conflict). In addition to that, this paper aims at documenting the effects of the two forms of conflict not only in terms of cognitive processes (such as leaming) but also in terms of relational processes (e.g., the perception of the partner). Thus, a set of relational measures (e.g. perceived threat, perceived contribution of the partner, conflict regulation) were included in the paradigm. Moreover, in the present experiment, conflict was introduced via a fictitious computer-mediated interaction. This procedure allowed keeping a record of the replies participants gave to the fictitious partner and thus analyzing the way they further interacted with him or her.

The type of conflict is expected to have an effect on the perception of the other person and the relationship with him or her. More specifically, relational conflict should lead participants into perceiving the partner as more threatening for their competence than the epistemic conflict. 
On the contrafy, after an epistemic conflict, participants should believe more strongly that the other's point of view can help them, and should find the relationship with their partner more positive than after a relational conflict. As far as conflict regulation is concerned, relational conflict should favor a conflict regulation based on the affirmation of one's own point of view (relational conflict regulation) whereas epistemic conflict should favor a mode of regulation focused on the understanding of the text (epistemic conflict regulation).

We do not expect the type of conflict to affect the amount of replies to the partner, because in both cases participants will be stimulated to react to the partner's disagreement. However, we think that these replies should vary in their content. Participants should be less assertive about which one of the two partners is correct after an epistemic conflict than after a relational conflict. They should also justify their answer to a larger extent, and express more doubt. Finally, as in Darnon et al. (2002), the epistemic conflict should lead to a better learning than the relational conflict.

\section{Method}

\section{Participants}

Thirty-four undergraduate French psychology students, 31 women and 3 men participated in this study in exchange of credit points. They were randomly assigned to one of the two conditions ( $N=17$ per condition) $)^{1}$.

\section{Procedure and material}

Two participants were scheduled for each time slot of 30 minutes. It was first explained that they would work cooperatively on a social psychology text and that they would communicate with the other person in a computer-mediated interaction. The text was about social categorization. It had been extracted from a social psychology textbook (Doise, Deschamps, \& Mugny, 1991) and rewritten in order to be easier and more understandable to undergraduate students.

In the present experiment, participants received identical information. As mentioned earlier, however, in previous research (Darnon et al., 2002), the effects of the type of conflict appeared only when participants had complementary information, that is, in a situation where interacting with the other person was perceived as highly relevant and where competitive issues were reduced (Buchs et al., 2004). Thus, to recreate the same kind of atmosphere, participants were first shown the importance of the complementarity of points of view and the advantages of taking into account the other's point of view (Gruber, 2000). This was illustrated through a task in which one of the participants looked inside a black box and saw a square, and the other participant looked inside from another opening and saw a triangle. When the participants declared that the two answers (square and triangle) were incompatible, and that they could not guess what was inside the box, the experimenter took out a pyramid and explained how important the others' point of view is (see Butera, Huguet, Mugny, \& Pérez, 1994, for more details on the task).

Then, they were seated in different cubicles, each one with a computer, and were given the specific instructions for using the computer. Separately, each participant was told that he/she would be the one who would answer first. The text was divided into four sections. For each section, one question was asked (see Appendix). Participants had a space on the screen to type their answer. They then sent their answer to "their partner", who in fact did not receive it. After waiting for a few seconds, they received the so-called "partner's answer", which in fact was a pre-recorded sentence sent by the computer (see next section). After receiving this answer, participants could either decide to reply to the partner or to continue, in which case the next part of the text appeared on the screen. The same procedure was repeated for the four questions. 
After this "interaction" phase, participants were asked to answer a questionnaire containing the self report measures of threat, perceived partner's contribution, quality of relationship with him/her, perceived amount of disagreement, and conflict regulation. Finally, they were asked to answer a multiple-choice test measuring how much they learned about the conflictual parts of the text.

\section{Independent variable}

The messages sent by the partner had been designed in order to induce different types of conflicts. The thetorical styles used to induce epistemic and relational conflicts were very close to those used in Damon et al. (2002). The argument's content was similar in the two conflict conditions, but the way it was introduced differed. In the epistemic conflict condition, the conflict was focused on the text. In the relational conflict condition, the conflict was presented in a way that questioned the participant's competences. To strengthen the credibility of the experimental manipulation, there were three disagreements and one agreement. The four pre-recorded answers in the two conflict conditions are presented in the Appendix.

\section{Dependent variables}

Perceived amount of disagreement. Perceived amount of disagreement was assessed by asking participants to report (on a scale ranging from 1 "very few" to 7, "very much") what was the amount of elements on which they and their partner did not immediately agree during the interaction ( $M=4.09, S D=1.42)$. Let us note that the way the conflicts were manipulated inplied necessarily the exact same number of disagreements (i.e., 3 ). In other words, what we wanted to assess with this question was not the number of disagreements but the perceived amount of disagreement in the interaction.

Conflict regulation. Conflict regulation items were similar to those used in previous research (Darnon, Muller, Schrager, Pannuzzo, \& Butera, 2006). Participants were asked to indicate to what extent, when disagreement occurred, they tried to (in the order they were presented): "examine the conditions under which each point of view could help them understand"; "think again about the text in order to understand better"; "think of a solution that could integrate both points of view"; "show they were right"; "show their partner was wrong". The first three items were aggregated in a score of epistemic conflict regulation $(\alpha=.73, M=4.62, S D=1.18)$ and the two last itens in a score of relational conflict regulation, $a=64, M=3.81, S D=1.41$ ).

Perception of the partner and of the relationship with him/her. As far as perception of competence threat is concerned, participants were asked to indicate how much they thought their partner "doubted their competence", "tried to impose his/her point of view", "tried to show he/she was more competent than thenselves" $(M=3.51, S D=1.55, \alpha=.74)$ on a scale ranging from 1 (not at all) to 7 (very much). Moreover, on three items, participants were asked to report the perceived contribution of the partner: "taking into account the other's point of view is..." on a scale ranging from 1 ("not very helpful") to 7 ("very helpful"); "Knowing the other's point of view..." on a scale ranging from 1 ("is confusing") to 7 ("clarifies thoughts"); "The partners" points of views are..." on a scale ranging from 1 ("independent") to 7 ("complementary"). These three items have been aggregated on a single score of perceived contribution of the partner $(M=4.75, S D=1.11, c=60)$. Finally, participants were asked to indicate, also on a scale ranging from 1 (very few) to 7 (very high) what was, in their relationship with their partner, the degree of cooperation, of competition (reversed score), of conflict (reversed score), the quality of the relationship, and the collaboration between them. These items have been aggregated in a score of perceived quality of the relationship ( $M=4.48$, $S D=1.19, \alpha=.76)$. 
Replies to the partner. After receiving the "partner's answer", participants had the opportunity to reply. The number of replies was recorded. There could be between 0 (never replied) and 4 replies (replied for all questions, $M=2.76, S D=.65$ ). Moreover, two independent coders, blind to the experimental conditions, coded the content of the replies. The replies in which the participants did not decide between the two propositions, that is, all the sentences on which they seemed to be uncertain about which one of the two propositions was the correct one (e.g., "I thought that...but indeed..."; "even if these two conditions are equivalent, isn't there 3 experimental conditions in this experiment?"; "Maybe it depends on...") were coded as "recognition of uncertainty". Moreover, a reply was coded as "justified" each time a participant gave an explanation (e.g., "In this case, they will choose to earn less money because what is important for them is to earn more than the other group, and not to earn a lot"). The replies in which the justification was not elaborated (e.g. "it is written in the text") were not included in this category. Replies were coded as "Referring to the other's point of view" each time participants referred to their partner's answer. For example, these replies could be: "I understand what you mean but..." or "you mean that...". The questions asked in order to better understand the other's point of view (e.g., "Do you mean that...?") and the solicitation of the other's point of view (e.g., "what do you think of...?") were included in this category. Finally, a reply was coded as "self-doubt" each time participants expressed a doubt, an uncertainty about their answer, like "I am not sure", "I don't know", "perhaps", or "I feel confused".

As there were 4 questions, the number of each type of reply for an experimental session could range from 0 to 4 . The overall inter-judge correlation is fair $(r=68)$. A proportion of occurrences of each type of reply has been calculated on the basis of the ratio between the number of occurrences of the specific type of reply and the total number of replies.

Learning. Learning was assessed through the grade obtained from a multiple-choice test, containing three questions assessing the understanding of the conflictual parts of the text. For example, one of the questions was: "What are stereotypes?" and one of the suggested answers was "people of a same group are perceived as similar between each others". One point was given for each correct answer. Negative points ( -0.25 for each mistakes) were given to incorrect answers, in order to reduce the risk that participants would answer randomly to the questions. Due to these possible negative points, this measure ranged from -.75 to +3 $(M=1.82, S D=1.08)$.

\section{Results}

\section{Preliminary analyses}

Intercorrelation among variables are presented in Table 1. Preliminary analyses of variance were performed in order to check whether the type of conflict created the same perceived amount of disagreement, that is, that the two types of manipulated conflicts varied in their quality but not in their quantity. These analyses revealed that the type of conflict had a significant and sizeable effect on the reported perceived amount of disagreement, $F(1,32)=12.16, p<.001, \eta^{2}=.28$. Participants in the relational conflict condition perceived the conflict as stronger $(M=4.82 ; S D=1.47)$ than participants in the epistemic conflict condition $(M=3.35 ; S D=.93)$. Thus, the variable "perceived amount of disagreement" has been included in the analyses as a supplementary independent variable. Regression analyses have then been performed to further analyze the data. The model tested in these regression analyses included three predictors: The type of conflict (coded -1 for relational conflict, +1 for epistemic conflict) and the amount of perceived conflict (continuous variable), as well as the interaction between these two variables (created from the centered variables, see Brauer, 2002; Judd \& McClelland, 1989). 
Table 1

Correlation among variables

\begin{tabular}{|c|c|c|c|c|c|}
\hline & (l) & (2) & (3) & $(4)$ & (5) \\
\hline (1) Perceived competence threat & 1 & & & & \\
\hline (2) Quality of the relationship & $-0,48 * *$ & 1 & & & \\
\hline (3) Perceived contribution of the partner & $-0,55^{\sharp * *}$ & 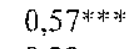 & 1 & & \\
\hline (4) Epistemic regulation & $-0,26$ & 0,23 & $0,43^{*}$ & 1 & \\
\hline (5) Relational competitive regulation & $0,50 * *$ & $-0,29$ & $-0,51 * *$ & $-0,36^{*}$ & 1 \\
\hline (6) Amount of replies & 0,10 & 0,06 & 0,12 & $-0,02$ & $0,38^{*}$ \\
\hline
\end{tabular}

The mean and standard deviation of each variable depending on the type of conflict are presented in Table 2.

Table 2

Means and Standard Deviation as a function of the type of conflict

\begin{tabular}{|c|c|c|c|c|}
\hline & \multicolumn{2}{|c|}{ Epistemic conflict $N=17$} & \multicolumn{2}{|c|}{ Relational conflict $N=17$} \\
\hline & $M$ & $S D$ & $M$ & $S D$ \\
\hline Perceived competence threat & $2.82 \mathrm{a}$ & 1.07 & $4.20 \mathrm{~b}$ & 1.67 \\
\hline Quality of the relationship & $5 a$ & .88 & $3.96 \mathrm{a}$ & 1.26 \\
\hline Perceived contribution of the partner & $5.29 b$ & .88 & $4.19 \mathbf{a}$ & 1.06 \\
\hline Epistemic regulation & $4.76 \mathrm{a}$ & 1.27 & $4.47 \mathrm{a}$ & 1.11 \\
\hline Relational competitive regulation & $3.45 a$ & 1.22 & $4.17 \mathrm{a}$ & 1.54 \\
\hline Amount of replies & $2.82 \mathrm{a}$ & .64 & $2.71 \mathrm{a}$ & .69 \\
\hline Learning & $2.15 \mathrm{~b}$ & .84 & $1.49 \mathrm{a}$ & 1.21 \\
\hline
\end{tabular}

Note. For each line, means with different subscript differ at a $p<.10$ level.

\section{Perception of the partner and of the relationship with him/her}

Perception of competence threat. The effect of the type of conflict on the perceived competence threat, $\beta=-.83, F(1,30)=8.46, p<.007, \eta^{2}=.22$ indicated that in the relational conflict condition, participants had the impression that their partner threatened their competence more than in the epistemic conflict condition. The amount of perceived disagreement had no main effect $F(1,30)<1$. However, the interaction between the two variables was marginal (but with a fair effect size, see Cohen, 1988), $\beta=-.40, F(1,30)=3.42$, $p<.08, \eta^{2}=10$. As can be seen in Figure 1, this interaction indicated that in the epistemic conflict condition, the stronger the participants perceived the conflict, the less they felt threatened $(\beta=-.60, p=12)$, while the opposite trend was observed in the relational conflict condition $(\beta=.21, p=.37)$. However these trends do not reach significance.

Perceived contribution of the partner. The effect of the type of conflict, $\beta=.56$, $F(1,30)=7.66, p<.01, \eta^{2}=.20$ indicated that after an epistemic conflict, participants reported being more convinced that their partner could allow a better understanding of the problem than after a relational conflict. Neither the perceived amount of disagreement, $F(1,30)<1$, nor the interaction between the variables, $\beta=-.23, F(1,30)=2.01, p=17$, reached significance.

Perceived quality of the relationship. The only significant predictor of perceived quality of the relationship was the perceived amount of disagreement, $\beta=.41, F(1,30)=6.36, p<.02, \eta^{2}=.18$. The more participants perceived disagreement, the less they perceived the relationship with their

\footnotetext{
"Erratum : all ßs are in fact Bs."
} 
partner as positive. Neither the type of conflict $\beta=.22, F(1,30)=1.06, p=.31$, nor the interaction $\beta=-.22, F(1,30)=1.94, p=.17$ significantly predicted the perceived quality of the relationship.

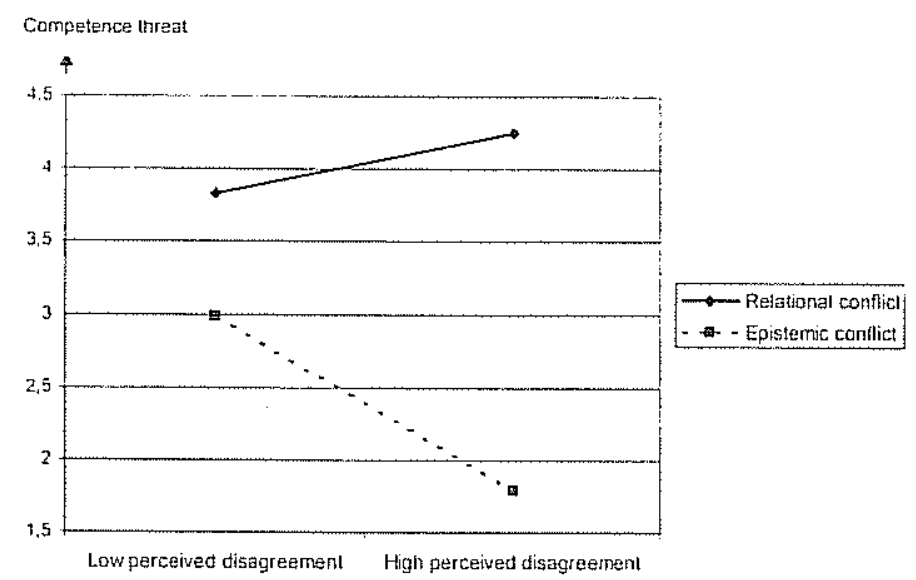

Figure 1. Link between perceived amount of disagreement and competence threat as a function of the type of conflict

\section{Conflict regulation}

Epistemic regulation. Regressing epistemic regulation on the model revealed neither a main effect of type of conflict, nor a main effect of perceived amount of disagreement, both $F \mathrm{~s}(1,30)<1$. However, a marginal interaction with a fair effect size between the amount of disagreement and the type of conflict, $\beta=.32, F(1,30)=3.11, p<.09, \eta^{2}=.09$ appeared. As can be seen in Figure 2, this interaction indicated that the perceived amount of disagreement was negatively linked to epistemic regulation in the relational conflict condition $(\beta=-.37, p<.07)$, which was not the case in the epistemic conflict condition $(\beta=.27, p=.39)$.

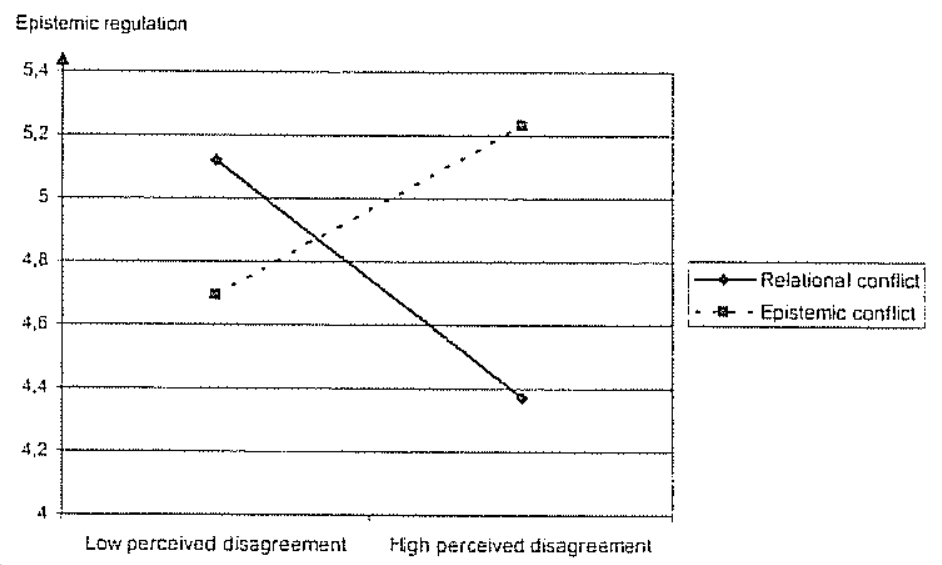

Figure 2. Link between perceived amount of disagreement and epistemic regulation as a function of the type of conflict

Relational regulation. Regressing relational regulation on the model also revealed a marginal interaction with a fair effect size between the amount of disagreement and the type of conflict, $\beta=-.40, F(1,30)=3.25, p<.09, \eta^{2}=.10$. As can be seen in Figure 3, the perceived amount of disagreement positively predicted relational regulation in the relational conflict condition $(\beta=.58, p<.03)$, which was not the case in the epistemic conflict condition $(\beta=-.22$, 
$p=.55$ ). As it was the case for epistemic regulation, neither the main effect of conflict, nor the main effect of perceived amount of disagreement were significant, both $F \mathrm{~s}(1,30)<1$.

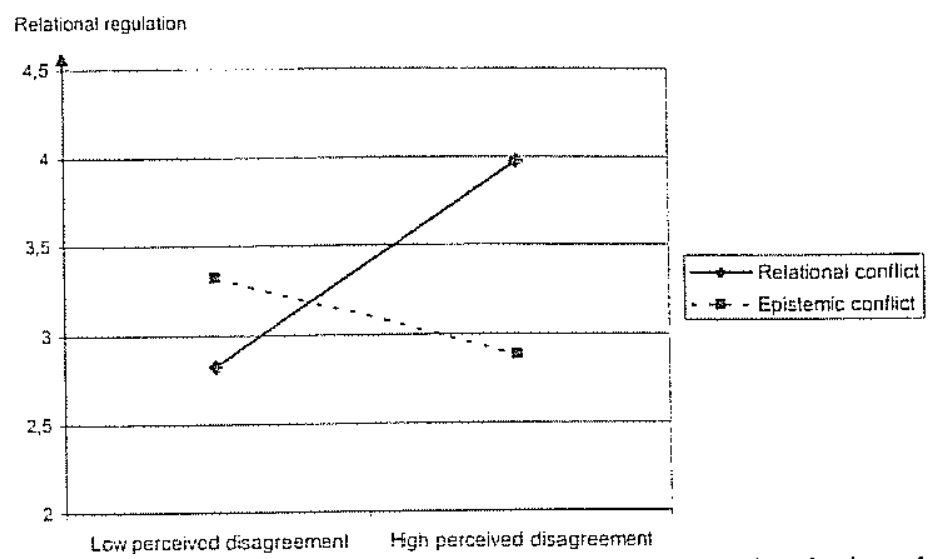

Figure 3. Link between perceived amount of disagreement and relational regulation as a function of the type of conflict

\section{Replies to the partner}

Amount of replies. The same model has been performed on the amount of replies. Neither the type of conflict, nor the perceived amount of disagreement, nor the interaction were significant predictor of the amount of replies, all $F s(1,30)<1$.

Content of the replies. Further analyses were carried out to determine if these replies varied in their content. The mean proportions obtained for each behavior are presented in Table 3.

Table 3

Mean proportion of behaviours in the replies to the partner.

\begin{tabular}{lccccc}
\hline & \multicolumn{2}{c}{ Epistenic conflict $N=17$} & & \multicolumn{2}{c}{ Relational conflict $N=17$} \\
\cline { 2 - 3 } \cline { 6 - 7 } & $M$ & $S D$ & & $M$ & $S D$ \\
\hline Recognition of uncertainty & $25.5 \% \mathbf{b}$ & 19.4 & & $5.9 \% \mathbf{a}$ & 14.4 \\
Justification & $74.5 \% \mathrm{~b}$ & 24.4 & & $47.1 \% \mathbf{a}$ & 34.5 \\
Self-doubt & $29.9 \% \mathrm{~b}$ & 20.8 & & $3.9 \% \mathrm{a}$ & 12.6 \\
\hline
\end{tabular}

Note. For ench line, means with different subscript differ at a $p<.05$ level.

The analyses revealed a main effect of the type of conflict on the recognition of uncertainty, $\beta=12.7, F(1,30)=13.11, p<.002, \eta^{2}=30$. Participants showed indecision about which answer was correct more often in the epistemic conflict condition than in the relational conflict condition. Neither the main effect of disagreement. $\beta=3.99, F(1,30)=2.2, p=15$, nor the interaction effect, $\beta=3.00, F(1,30)=1.24, p=.27$ reached significance.

As far as justifications are concemed, a marginal, but sizeable, effect of type of conflict was observed, $\beta=10.96, F(1,30)=3.01, p<.10, \eta^{2}=.09$. This effect indicated that participants tended to justify their answers more often after an epistenic conflict than after a relational conflict. The amount of disagreement, as well as the interaction were not significant predictors of this behavior, both $F_{\mathrm{S}}(1,30)<1$.

Finally, the main effect of type of conflict on self-doubt, $\beta=16.05, F(1,30)=20.6, p<.001$, $\eta^{2}=41$, indicated that after an epistemic conflict, participants expressed more doubt in their answer than after a relational conflict. 


\section{Learning}

Finally, the effect of the type of conflict on learning, $\beta=.39, F(1.30)=3.01, p^{<.10}, \eta^{2}=.09$, marginal but with a fair effect size, indicated that the epistemic conflict tended to lead to a better learning than the relational conflict. Neither the main effect of perceived amount of disagreement, nor the interaction were significant predictors of learning, both $F_{S}(1,30)<1$.

\section{Discussion}

The aim of this research was to examine the consequences of the confrontation to epistemic vs. relational conflict on learning, perception of the disagreeing partner, and interaction behaviors.

The first important result is that the type of conflict did not lead to the same perceived amount of disagreement: Participants who faced a relational conflict perceived the disagreement as stronger than did participants who were confronted with an epistemic conflict. Even if this difference was unpredicted, it can easily be understood. Indeed, other analyses indicated that the type of conflict modified the way the conflict was perceived. The epistemic conflict enhanced the perceived contribution of the partner. On the contrasy, the relational conflict enhanced the perceived competence threat. This could explain why under relational conflict, more than under epistemic conflict, the disagreement makes salient competence issues and is perceived as strong.

This point suggests the importance of taking into account not only the type of conflict (its quality), but also its strength (the quantity) in understanding its effects. The rest of the analyses confirmed that these two dimensions of conflict, quality on the one hand, quantity on the other hand, affected different processes. As far as the relationship is concerned, and contrary to what was expected, what mattered was the quantity of conflict. The stronger the perceived conflict, the less positive was the relationship. As far as perceived partner's contribution and perceived competence threat are concerned however, what mattered was the nature of the conflict. The epistemic conflict led participants into thinking that the partner's answers could help them more than the relational conflict. It also reduced the perception of the partner as a threat to selfcompetence. The same observation can be made for the interaction behaviors following a conflict. Indeed, what determined participants to further interact with the partner was not the quantity of conflict, but its quality. After a relational conflict, participants replied as much as after an epistemic conflict; however, their replies were not of the same type. Indeed, they contained more indecisions, more justifications, and more self-doubt after an epistemic conflict than after a relational conflict. Let us note finally that the effect of the type of conflict on learning allowed replicating the effect observed in previous research (Darnon et al., 2002): better learning was observed under epistemic conflict rather than under relational conflict. Even if the effect is only marginal, its size is not negligible.

The above variables were affected either by the nature of the conflict (its quality), or by its strength (perceived quantity). Interestingly, conflict regulation seemed to depend on the interaction between the quantity and the quality of conflict. Indeed, the strength of conflict affected differently its regulation according to its form. When the conflict was epistemic, the stronger the perceived conflict, the more participants said they worked through the problem to understand it better and tried to integrate the two points of views, that is, the more they regulated conflict in an epistemic way. On the contrary, after a relational conflict, the stronger the perceived conflict, the more participants said they tried to assert they were right and the other person was wrong, that is, the more they engaged in a relational regulation of conflict. It has already been shown in previous research (Darnon \& Butera, in press) that depending on the context, the perceived amount of disagreement could predict either one or the other of these modes of conflict regulation. In this previous research, the experimental context varied as a function of goals (either mastery, or performance goals, Dweck, 1986). Evidence is brought here that similar dynamics are observed with different forms of conflict. 
This research has some limitations that are worth mentioning. Notably, it would have been interesting to have some conditions without conflict. More specifically, future research should examine the effects of two agreements conditions that, as our conflict conditions, vary in the way the agreement is fomulated. This would allow determining if the effects observed here are due to conflict regulation processes or to some more general processes that would occur independently of the conflict.

Despite this limitation, the results of the present study corroborate the idea that the rhetoric used to express a conflict highly influences the way it is perceived, regulated, and the way people further interact with each others. It also tended to moderate its effect on learning. To come back to the introductory example, these results underlined how inportant it is, when expressing a disagreement with another person, to pay attention to the rhetoric used to express it. Many authors have shown that in our society, conflict is often perceived as a "bad thing", a relational issue to avoid as much as possible (Johnson, Johnson, \& Tjosvold, 2000; Pérez, Mugny, Maggi, Falomir, \& Butera, 1995). This is probably the reason why, when people discuss issues, even a very subtle reference to competence can be enough to make the conflict switch from the epistemic issue to the relational issue. And this research showed that in this case, conflict will be perceived as stronger, more threatening and less helpful. Moreover, it created a context in which the stronger the individuals perceived the conflict, the more they regulated it in a relational way. Even more importantly, this type of conflict resulted in poorer learning than if it had been presented in a non threatening way.

Most of the learning environments are environments in which an individual is not only confronted to a task to be learnt but also to other persons. And in such a social context, the discussion of divergent points of view is particularly likely to occur. Indeed, be it in a conference, a classroom, a discussion or any context in which knowledge is likely to be discussed, conflict is a very common situation. Examining these kinds of conflict and specifying the conditions in which those conflicts can be constructive is in this sense particularly relevant. What the present research indicates is the importance, in such situations, to pay great attention to the rhetoric underlying the expression of a conflict. As mentioned earlier, each of us have probably experienced such conflicts and will probably experience others. Based on this research, the recommendation, in this kind of situations, is to make sure the way one presents the conflict will not orient the individuals' attention toward the question of competence, but toward the content of the discussed knowledge. This will be a good way to enhance the benefits one gains from this kind of confrontation.

\section{Appendix}

Manipulation of epistemic and relational conflicts

\begin{tabular}{|c|c|c|}
\hline Questions: & Epistenic conflict & Relational conllict \\
\hline $\begin{array}{l}\text { 1- In this experiment, how many } \\
\text { experimental conditions are there } \\
\text { and what are they? }\end{array}$ & $\begin{array}{l}\text { I hough "randomly assigned" and } \\
\text { "not chassified" "rere identical. }\end{array}$ & $\begin{array}{l}\text { No, vot didn' ' get it. "romdombl assigned" } \\
\text { and "not classified" are identical. }\end{array}$ \\
\hline $\begin{array}{l}\text { 2- Does this paragraph lead into thinking } \\
\text { lhat the bias observed in lines percepion } \\
\text { (as in Tajfel and Willes s experiment) } \\
\text { also concems person perception (social } \\
\text { stereorypes)? }\end{array}$ & $\begin{array}{l}\text { It seems weird to me that this } \\
\text { experimen on lines cond be } \\
\text { related to social stereonpes... }\end{array}$ & $\begin{array}{l}\text { Exouse no bu lines and social } \\
\text { stereotipes have definitel nothing } \\
\text { in common. }\end{array}$ \\
\hline $\begin{array}{l}\text { 3- In this experiment, are groups } \\
\text { created rindomly or according to } \\
\text { pre-existing relationsipips? }\end{array}$ & I agree. & I agreé. \\
\hline 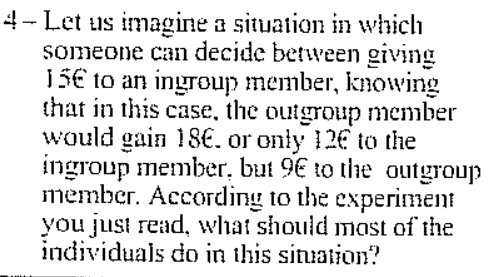 & 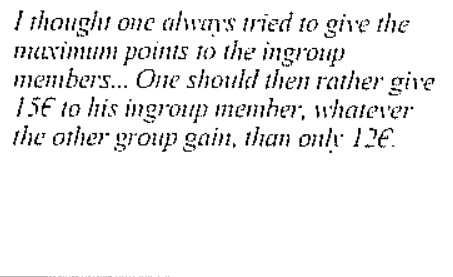 & 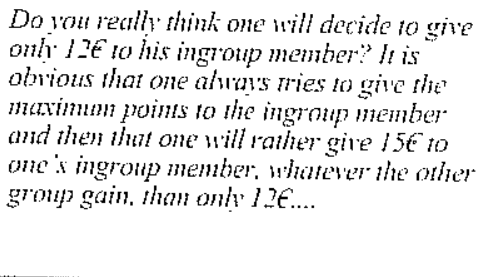 \\
\hline
\end{tabular}




\section{Notes}

1 It is worth noting that the sample is mainly composed of women. which reflects the distribution of students in the department of psyciology. All the presented effects remained significant when analyses were perfomed without the three male participants.

\section{References}

Baron, R.A. (1988). Negative effects of desirtuctive criticism: Impact on conflict. self-efficacy. and task performance. Journal of Applied Psichologr, 73, 199-207.

Berlyne. D.E. (1960). Conflict, arousal, and curiosity: New York: McGraw-Hill.

Brauer, M. (2002). L'analyse des variables indépendantes continues et catégotielles: Alternatives à la dichotonisation. L'Année Psychologigue, 102. 449-484.

Brennan, J.G., Miller, L.E., \& Selizer, J. (1993). Influence tactics and effectiveness. The Joumal of Social Psycholog:, $133,747-748$.

Buchs. C., Butera, F., \& Mugny, G. (2004). Resource interdependence, student interactions and performance in cooperative learning. Educational Psychology, 24, 291-314.

Buchs, C.. Butera, F., Mugny, G., \& Darnon, C. (2004). Conflict elaboration and cognitive outcomes. Theory Into Practice, 43, 23-30.

Buters, F., \& Buchs, C. (2005). Reasoning together: From focussing to decentring. In V. Girotto \& P.N. Johnson-Laird (Eds.), The shape of reason (pp. 193-203). Hove, UK: Psychology Press.

Butera, F., \& Mugny, G. (1995). Conflict between incompetences and infuence of a low expenise source in thypothesis testing. European Journal of Social Psychology, 25, 457-462.

Butera, F., \& Mugny, G. (2001). Conflicts and social influences in hypothesis testing. In C.K.W. De Dreu \& N.K. De Vries (Eds.), Group consensus and minority influence. Implications for innovation (pp. 161-182). Oxford: Blackwell.

Butera, F., Mugny, G., \& Tomei, A. (2000). Incertitude et enjeux identitaires dans l'influence sociale. In J.L. Beauvois, R.V. Joule, \& I.M. Monteil (Eds.), Perspectives cognitives et conduites sociale (vol. VII, pp. 205-229). Rennes: Presses Universitaires de Rennes.

Butera, F., Gardair, E., Maggi, J., \& Mugny, G. (1998). Les paradoxes de l'expertise: Influence sociale et (in) compétence de soi et d'autrui. In J. Py, A. Somat, \& J. Baillé (Eds.). Psychologie sociale et formation professionnelle: Propositions et regards critiques (pp. 11 1-123). Rennes: Presses Universitaires de Rennes.

Bulera, F., Huguet, P.. Mugny, G., \& Pèrez, J.A. (1994). Socio-epistemic conflict and constnuclivism. Suiss Jommal of Psichology, 53. 229-239.

Cohen. J. (1988). Statistical power andysis for the behavioral sciences (2nd edition). Hillsdale. NJ: Erlbaum.

Damon, W.. \& Kilen, M. (1982). Peer interaction and the process of change in children's moral reasoning. MerrillPalmer Quarterly, 28, 347-367.

Darnon, C.. \& Butera, F. (in press). Learning or succeeding? Conflict regulation with mastery or perfonnance goals. Swiss Ioumal of Psycholog\%.

Darnon, C., Buchs, C., \& Butera, F. (2002). Epistemic and relational conflict in sharing information during cooperative learning. Siriss Joumal of Psychologn, 61, 139-151.

Darnon, C., Butera, F., \& Harackiewicz, 3. (2007). Achicvement goals in social interactions: Leaming with mastery vs. pertormince goal. Motivation and Enotion, 31.61-70.

Damon, C., Muller, D., Schrager, S.M.. Panmuzzo, N., \& Butera, F. (2006). Mastery and performance goals predict epistemic and relational conflict regulation. Jounal of Educational Psychology, 98, 766-776.

Doise, W. \& Mugny, G. (1984). The social development of the intellect. Oxford: Pergamon Press. 
Doise, W., Deschamps, J.C.. \& Mugny, G. (1991). Psychologie sociale expérimentale. Paris: Amand Colin.

Dweck, C.S. (1986). Motivational processes affecting learning. American Psychologist, 41, 1040-1048.

Gruber, H.E. (2000). Creativity and conflict resolution: The role of point of view. ln M. Deutsch \& P.T. Coleman (Eds.). The handbook of conflict resolution: Theory and practice (pp. 345-354). San Francisco: Jossey-Bass Inc Publishers.

Johnson, D.W., \& Johnson, R.T. (1985). Classroom conflict: Controversy versuts debate in leaming groups. American Educational Research Journal, 22, 237-256.

Johnson. D.W.. \& Johnson, R.T. (1994). The pro-con cooperative group strategy: Structuring academic controversy within the social studies classroom. In R. Stahl (Ed.), Cooperative learning in social studies: A handbook for reachers (pp. 306-331). New-Y'ork: Addison-Westley Publishing Company.

Iohnson, D.W.. Johnson, R.T., \& Smith, K. (2000). Constructive controversy, the educative power of intellectual conflict. Change, 32. 29-37.

Jolnson. D.W., Johnson. R.T.. \& Stanne, M.S. (1989). Impact of goal and resource interdependence on problem solving success. The Journal of Social Psychologr, 129.621-629.

Jehnson, D.W., Johnson. R.T. \& Tjosvold, D. (2000). Constructive controversy: The value of inteliectual opposition. In M. Deutsch \& P.T. Coleman (Eds.), The handbook of conflict resolution: Theorn and practice (pp. 65-85). San Francisco: lossey-Bass Ine Publishers.

Judd. C.M., \& McClelland, G.H. (1989). Dara analysis: A model comparison approach. San Diego: Harcoun, Brace, Jovanovich.

Krauss, R.M., \& Morsella, E. (2000). Communication and conflict. In M. Deuisch \& P.T. Coleman (Eds.), The handbook of conflict resolution: Theory and practice (pp. 131-143). San Francisco, CA: Jossey-Bass Inc, Publishers.

Lambiotte, J., Dansereau. D., O'Donnell, A., Young, M., Skaggs, L., Hall, R., \& Roclilin, T. (1987). Manipulating cooperative scripts for teaching and leaming. Joumal of Educational Pyschology, 79, 424-430.

Lowry, N., \& Johnson, D.W. (1981). Effect of controversy on epistemic curiosity, achievement and attitudes. The Joumal of Social Psychology, 115, 31-43.

Maggi, J., Mugny, G., \& Papastamou, S. (1998). Les styles de compontement et leur représentation sociale. In S. Moscovici (Ed.). Psychologie sociale. Paris: Presses Universitaires de France.

Monteil, J.M., \& Chambres, P. (1990). Eléments pour une exploration des dimensions du conflit socio-cognitif: Une expérimentation chez. l'adulte. Revue Imemationale de Psychologie Sociale, 4. $499-517$.

Mugny, G. (1982). The pouter of minoritier. London: Academic Press.

Mugny, G., Chatard, A., \& Quiamzade, A. (2006). The social transmission of knowledge at the university: Teaching style and cpistemic dependence. European Joumal of Pswchology of Edmotion, MX7(4), 413-427.

Mugny, G., De Paolis, P., \& Carugati, F. (1984). Social regulations in cognitive development. In W. Doise \& A. Palmonari (Eds.). Social interaction in individual development (pp. 127-146). Cambridge: Cambridge University Press.

Mugny, G. Tafani, E. Butera. F., \& Pigiere, D. (1999). Contrainte et dépendance informationnelles: Influence sociale sur la représentation du groupe d'anis idéal. Commexions, 72, 55-72.

Mugny. G.. Burera. F.. Quimzade, A., Dragulescu, A., \& Tomei, A. (2003). Comparaisons sociales des competences et dynamiques d'influence sociale dans les tâches d'aptitudes. $L$ Amée Psychologiture. 104. 469-496.

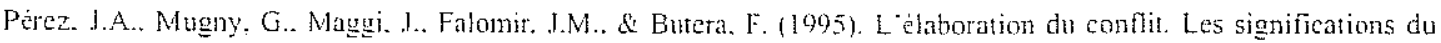
conflit dans l"influence sociale. Psychoscope. 2. 11-14.

Quiamzade, A., \& Mugny. G. (2001). Social influence dynamics in aptitude tasks. Socint Fsychology of Edhcation, 4. $311-334$.

Quiamzade. A.. Tomei. A.. \& Butera. F. (2000). Informational dependence and infomational constraint: Social comparison and social influences in an anagran resolution task. Revte htowationale de Psychologie Sociale, 15, 123+150.

Quiamzade, A., Mugny, G.. Dragulescu. A., \& Buchs. C. (2004). Interaction slyles and expert social influence. European Joumal of Psychology of Edhation. $17 \% / 4(4)$. 389-404. 
Quiamzade, A., Mugny. G.. Falomir, J.-M., Invernizzi. F., Buchs. C., \& Dragulescu. A. (2004). Correspondance entre style d influence et significations des positions initiales de la cible: Le cas des sources expertes. in J.-L. Beauvois. R.-V. Joule. \& J.-M. Monteil (Eds.). Perspectine's cognimives et conhihts sociales (vol. 9. pp. 341-363). Rennes: Presses Universitatires de Rennes.

Smith. K.. Johnson. D.W.. \& Johnson, R.T. (1981). Can conflict be constructive? Controversy versus concurrence seeking in tearning groups. Journal of Educationul Psychologr. 73. $651-663$.

Tjosvold, D. (1989). Cooperative and competitive goal appronch to conflict: Accomplishments and challenges. Applied Psycholog: An Hiternational Review, 47, 285-342.

Tjosvold. D.. Johnson. D.W., \& Fabrey, L.J. (1980). Elfect of controversy and defensiveness on cognitive perspective taking. Psychological Reports. 47, 1043-1053.

Tjosvold, D.. Johnson, D.W., \& Lerner, J. (1981). Effects of affinnation and acceptance on incorporation of opposing information in problem solving. The Jounal of Social Psychology. 114. 103-110.

Tomasetto, C (2004). Influence style and students' orientation toward extra-cumicular activities: An application of the cortespondence hypothesis. European Joumal of Psychology' of Education, XXX(2), 133-145.

Van Knippenberg, B., \& Steensma, H. (2003). Future interaction expectation and the use of soft and hard influence tactics. Applied Psycholog: An Intenational Review, 52, 55-67.

Yuk, G.. \& Tracey, J.B. (1992). Consequences of influence tactics used with subordinates, peers, and the boss. Journal of Applied Psychology, 77, 525-535.

La présente expérience a examiné les effets de conflits épistémiques vs. relationnels avec un partenaire. Des étudiants étaient amenés à participer à une pseudo-interaction médiatisée par ordinateur avec un partenaire factice, à propos d'un texte. Ce partenaire factice introduisait soit un conflit épistémique (un conflit se référant au contenu du texte) soit un conflit relationnel (un conflit qui mettait en cause la compétence des participants). Les résultats ont indiqué que comparativement au conflit épistémique, le conflit relationnel a augmenté la menace et réduit la contribution perçue du partenaire. De plus, après un conflit relationnel, les participants se sont montrés plus assertifs dans leurs réponses, les ont moins justifiées et ont exprimé moins de doutes qu'après un conflit épistémique. Les résultats indiquent également que l'intensité des désaccords prédit différents modes de régulation en fonction du tope de conflit. Enfm, le conflit épistémique a entrainé un meilleur apprentissage que le conflit relationnel.

Key words: Conflict, Epistemic regulation, Leaming, Relational regulation, Threat.

Received: June 2006

Revision received: February 2007

Céline Darnon. Laboratoire de Psychologie Sociale et Cognitive (LAPSCO), UMR CNRS 6024, Université Blaise Pascal, 34, Avenue Canot, 63037 Clermont-Ferrand Cedex, France. E-mail: celine.damon@univ-bpclermont.fr; Web site: www.darnon.sociajpsychology.org

Current theme of research:

Achievement goals and conflict regulation. 
Most relevan publications in the field of Psychologr' of Education:

Damon, C., Buchs, C., \& Butera, F. (2006). Buf de performance et de maîtrise et interactions sociales entre étudiants: La situation particuliẻre de désaccord avec autrui, Relıe Française de Pédagogie, 155, 35-44.

Darnon, C.. \& Butera, F., \& Harackiewicz, J.M. (2007). Achievement goals in social interactions: Leaming with mastery vs. performance goal. Mothation and Emotion, 31, 61-70.

Darnon, C.. Harackiewicz, J.M., Butera, F., Mugny, G., \& Quianzade, A. (2007). Performance-approach and performance-avoidance goals: When uncertainty makes a difference. Personality and Social Psychology Bulletin,
33. $813-827$.

Darnon, C., Multer, D., Schrager, S.M., Butera, F., \& Pannuzzo, N. (2006). Mastery and performance goals predict epistenic and relational conflict regulation. Joumal of Edicational Psychologi', 99, 766-776.

Sébastien Doll. Laboratoire de Psychologie Sociale de Grenoble-Chambéry, Université Pierre Mendès France, SHS, BP 47, 38040 Grenoble Cedex 9, France.

Current theme of research:

Conflict. Stereotype threat.

Fabrizio Butera. Institut des Sciences Sociales et Pédagogiques, Université de Lausanne, Anthropole, $\mathrm{CH}$ 1015, Lausanne, Suisse. E-mail: fabrizio.butera@unil.ch; Web site: www.unil.ch/ps

Curren thene of research:

Cooperation and competition in learning

Most relevant publications in the field of Psycholog' of Education:

Altherr, A.M., Mosler, H.J., Tobias. R., \& Butera, F. (in press). Attitudinal and relational factors predicting the use of solar water disinfection: A fieid study in Nicaragua. Health Education \& Behavior.

Buchs, C., \& Butera, F., \& Mugny, G. (2004). Resource in(ter)dependence, student interactions and performance in cooperative leaming. Educational Psychologn: 24, 291-314.

Butera, F.. \& Buchs, C. (2005). Reasoning together: From focussing to decentring. ln V. Girotio \& P.N. Jolnson-Laird (Eds.), The shape of reason (pp. 193-203). Hove, UK: Psychology Press.

Butera, F.. Jolnson. R., Johnson, D., Mugny, G. (Eds.). (2002), Learning at the University. Beme: Hans Huber. Special issue of the Swiss Joumal of Psychology.

Darnon. C. \& Butera, F. (2005). Buts d'accomplissement, stratégies d'étude, et motivation intrinséque: Présentation d'un domaine de recherche et validation Française de l'échelle d'Elliot et McGregor (2001). L'Amée' Psychologique, 105, 105-131. 